\title{
KHIDMAH; STUDENT DEVOTION TO THE TEACHER (A Brief Review)
}

\author{
Ahmadun Najah ${ }^{1,2}$ \\ 1'Islamic Boarding School of Jagad Alimussirry Surabaya, Indonesia \\ ${ }^{2}$ Faculty of Economics and Business UIN Sunan Ampel Surabaya, Indonesia
}

\begin{abstract}
One of the distinctive cultures that live sustainably in the boarding school environment is the khidmah tradition. Khidmah is interpreted as an attitude and wholehearted devotion activity carried out by a santri to his kyai or teacher, both during the study period at the boarding school or after graduation. Among Islamic boarding schools, this khidmah tradition has been deeply rooted since ancient times and is still maintained until now, and it is felt that it will persist into the future. More than just a tradition, this khidmah becomes an important identity of a santri as well as one of the benchmarks for his success in studying because in Islamic boarding school education. This study tries to explain the meaning and forms of khidmah, the factors behind the emergence of khidmah, motivation for khidmah, the theological basis of khidmah, as well as its virtues and benefits so that people can understand this khidmah problem more deeply and completely. This research is qualitative in the form of a literature study, with a conceptual approach to Sufism and morality. So it is possible to answer some aspects of the problem as mentioned earlier. After extracting the data and analyzing it, in this study several conclusions were obtained, including; first, khidmah is a form of devotion and service performed by a student (santri) to his teacher (kyai), as a form of respect and obedience to the teacher. This devotion can be in the form of devotion that has physical nuances, thoughts, possessions, or in the form of prayer. Second, the emergence of a khidmah tradition in Islamic boarding schools and other Islamic educational institutions is motivated by several factors such as strong moral education, especially morals for teacher (kyai), kyai who is believed to be pious and holy people, and the dormitory life system in the community a long period which builds an inner closeness between teacher and student. Third, some of the motivations that encourage students to be khidmah are to get the kyai's willingness (ridha) as well as an expression of gratitude and want to repay the kyai's services..
\end{abstract}

Keywords: khidmah; teacher; student;

\section{INTRODUCTION}

In the tradition of Islamic boarding school life, the relationship between teacher and student has a deep meaning and distinctive value, in such a way, which is different from general educational institutions or other Islamic educational institutions. The specificity in question is because the student (santri) places his teacher (kyai) as a highly venerated, loved, and respected figure at the same time. In the soul and mind of the santri, the kyai is an idol, important, central figure, and has done a lot in his life. This kind of view then gives birth to attitudes and behaviours 
that glorify the kyai, are obedient to the kyai, loyal, and desire to serve the kyai. The latter among the santri came to be known as khidmah (to serve, to serve and to be devoted) to the kyai wholeheartedly.

Indeed, the khidmah tradition that has developed and is sustainable from generation to generation in Islamic boarding schools is a form of embodiment of the main moral principles of a thalibul 'ilm (student of knowledge) to teachers, namely ta'dhimus syaikh / ta'dhimul ustadz / ta'dhimu expert. 'ilm (respecting the teacher). (az-Zarnuji, 2013; Asy'ari, Ttt.; Ba'athiyah, 2018).

It is well known that in Islamic educational institutions, especially in Islamic boarding schools, moral education is highly emphasized and prioritized. It is not just a science or theory but becomes a very vital aspect, so it is not an exaggeration to say that morality is the principle and spirit for Islamic boarding school. One aspect of morals that is instilled in the students from an early age is the morals of the teacher called ta'dhimus sheikh earlier. This problem, apart from being firmly cultivated in everyday life, is also instilled through the recitation of related moral books, including the legendary book Ta'limul Muta'allim which is full of important lessons and advice about the etiquette of seeking knowledge, one of which is is the ta'dhimus aspect of the sheikh.

Thus, as an Islamic educational institution that is certainly solid with scientific and spiritual values, every tradition that lives and takes root in Islamic boarding school does not just appear. The sunnah ma'hadiyah (sacred values of Islamic boarding schools), can be believed to come from; straight religious teachings, spiritual depth and wisdom of the kyai, as well as the noble values that exist in society. This paper will then briefly review the khidmah tradition that has been entrenched in Islamic boarding school, including its understanding and forms, factors and motivations, orientation and benefits, theological foundations, and their relevance in modern life.

\section{METHOD}

This type of research is qualitative research, which examines the pattern of human behaviour and what is the meaning behind the behaviour, to produce descriptive data in the form of written or spoken words from people and observable behaviour. This research was conducted with a phenomenological perspective, which departs from existing reality, with the main assumption that human behaviour has meaning for the perpetrator in a certain context. (Ahmad, 2011). The behaviour and reality that will be the object of study is the khidmah tradition in the pesantren. In terms of its nature, this is a descriptive study. That is to describe accurately the characteristics of an individual, a situation and a symptom. In this case, the author wants to describe as much as possible some things related to khidmah. Meanwhile, in terms of form, this is a literature study, because the sources of data used are all from library data in the form of yellow books, books, and articles. A literature study like this is a very important step, in fact, it is the essence of the research itself. So there is an adage, six hours in library save six months in field or laboratory. (Faisar and Watni, 2018). 
From the aspect of the approach, the model used is a conceptual approach that is intended to analyze a problem so that the meaning contained, in other words, is to analyze the concept of several meanings (Hajar, 2017). Of course, what will be the object of study is related to the concept of khidmah, which developed in the Islamic boarding school environment. The sources of data in this study all come from library data, both classical and modern books, both in Arabic and Indonesian. I try to refer to authoritative ulama's books and relevant themes so that they can produce weighty and reliable data.

Data collection techniques are carried out by conducting a review study of books, books, notes, and reports that are related to the problem being discussed. In this case, when browsing through the books, I focused on themes related to the manners of students to teachers, ta'dhimus shaykh, khidmah, blessings of knowledge, and manners of seeking knowledge in general. For data analysis, because the data is descriptive and textual, I use content analysis techniques. In this content analysis, the author does not only use personal reflective reasoning but also uses a linguistic approach and includes the opinions of famous scholars.

\section{RESULT AND DISCUSSION}

\section{A. Understanding and Forms of Khidmah}

As for the terms and this understanding will be used consistently in this paper as mentioned in the previous section, khidmah is a form of devotion carried out by a santri to his kyai, ustadz, or teacher sincerely, happily, obediently and earnestly which comes from the urge to glorify and love the teacher. Various examples of expressions that use the word khidmah above indicate that khidmah is an activity of devotion and service that is carried out sincerely and sincerely, which is motivated by voluntary will or because of duty, both in the scope of personal relations or within the scope of the institution.

In the tradition of Islamic boarding school life, the term khidmah was originally defined more as the work of devotion, service, or devotion of a santri to his kyai, with full sincerity, respect, submission, and sincerity. Here wisdom can take various forms. Among other things, such as always cleaning the kyai's residence and yard, helping to cook in the kitchen for the kyai and his family, washing the kyai's clothes, making and serving drinks for the kyai and guests, caring for and nurturing the kyai's sons and daughters, shopping at the market, watering flowers or plants in the area. the kyai's living environment, keeping the kyai's sons and daughters to school, become the kyai's barber, massage the kyai, care for or herd the kyai's pets, prepare the equipment needed by the kyai in teaching, become the cleric's clerk, help the kyai in his trade, accompany and even become the kyai's driver when traveling, guard the kyai against parties who will interfere, and so on, which in general are helping to meet the needs of the kyai and his family, as well as doing everything that is ordered or leave what is forbidden by the kyai. These forms of kidmah by some people are called khidmah bil-badan (physical devotion).

The last one is khidmah bid du'aa. That is continuously praying for the kyai and his family. Praying to Allah Ta'ala that the kyai be given guidance and help in educating students and leading the pesantren, given health and protection, and that his sins be forgiven by Allah Ta'ala. 
In reality, it may be that a santri (whether when he was a student or graduated) only did one kind of khidmah or not at all, while others could do some forms of khidmah at the same time, or some could even do it all at once. All of that is more determined by his sincerity, belief, and sincerity to serve, besides being influenced by opportunities and abilities. On the other hand, if previously khidmah was more personal in the form of voluntary devotion of a santri to the kyai and his family, then in its current development in some pesantren, khidmah has been transformed into a programmed collective activity initiated by the pesantren. An example is the existence of the khidmah tarbawiyah program, which is a service activity in the field of education and teaching carried out by a group of students in remote Islamic boarding schools for a certain period that is not too long, which is required by the pesantren. Likewise, there are Islamic boarding schools that require students to have a khidmah (devotion) program for 1 year after graduation, which is commonly known as being a duty teacher. Khidmah like this, even though it is not intended directly for the kyai himself, is part of the obedience to the kyai's orders and the practice of practising and disseminating the knowledge that has been acquired during his studies in the community.

Of course, other forms of khidmah have not been mentioned here, according to the rich experience of millions of santri in serving their kyai and the various characteristics of each pesantren in various places.

\section{B. Factors Behind Khidmah}

In this section, we will review and examine the reasons behind the emergence of the khidmah tradition in the Islamic boarding school among others;

First, the high attention to moral aspects in Islamic boarding schools. Moral education is something that is very basic and takes precedence over other aspects. This is understandable because religious teachings do place morals as something very important and have a high position, in addition, because the salaf scholars have reminded the importance of studying morality before science, with their famous saying "al-adab qablal 'ilm" namely " adab before knowledge".

In this context, one of the morals that is highly emphasized is in terms of ta'dhimus shaykh (glorifying teachers). The understanding of the ta'dhimus sheikh's adab, apart from being conveyed through the Koran, is also instilled through civilizing the practice of good manners (tata karma) to the kyai, in everyday life in pesantren in various activities and opportunities. This culture is massive, constant, and strict so that it becomes a living tradition and eventually becomes firmly attached, ingrained in a santri. The ta'dhimu shaykh's tradition of ta'dhimu is so strong and so attached that those who are not used to it can judge it as something strange or excessive. Well, in turn, the ta'dhimus sheikh character that animates a santri raises a strong urge to submit, obey, and serve the kyai (khidmah).

Second, the kyai factor is seen as a perfect figure. A kyai especially in the past has a special station in the eyes of the santri, or society in general. Not infrequently, for a santri, the kyai is believed to be a 'holy' figure, who is a 'lover of God'. It is understood that the position of the kyai is not easy to obtain and not just anyone can achieve it. All of this makes the students make the kyai a murobbi and role model in terms of knowledge, obedience, worship, morals, and mu'amalah. Furthermore, the kyai is believed to be the owner of an efficacious prayer, can be a wasilah to 
obtain blessings, and have the right hunch to be asked for advice on various issues. In short, kyai have a strong magnet to be respected, obeyed and loved. This special station was obtained by the kyai, apart from his broad mastery of religious knowledge, but also because of his spiritual height and noble character. Besides, of course, because of the great struggle and sacrifice that has been given to the students and the community, by teaching science and preaching. Above all, we can agree that the kyai in carrying out the mandate of education and teaching, both to students and the community, do so sincerely so that Allah gives fadl (priority) because of their sincerity. So that, the figure of the kyai who has a noble position (karomah), perfect (kamal), and authoritative (haibah) in the hearts of the students, gives birth to the urge to serve (khidmah) the kyai as an expression of respect for a figure who is admired, idolized, and loved at the same time.

Third, the factor of the pesantren education model that implements a collective dormitory/lodging life, where the santri live (mukim) in the cottage with the kyai for a long period of years. This naturally creates closeness and a strong inner bond between santri and kyai, including among fellow students. Living together, day and night for years in the pesantren under the guidance and guidance of the kyai - not only in the religious sciences - but also in the social sciences, leadership, and various life sciences certainly leaves an impression and deep inner experience, which is very meaningful and not easy forgotten. Especially for most people, that religious knowledge and things that can lead to God and the truth, are considered as something very important and basic, and all of that they have obtained from the kyai. Well, the existence of the kyai, who is very meaningful and close, then gave birth to the urge to be khidmah to the kyai, who is already considered a parent, even exceeding the role of the parents themselves in their services in the field of education and teaching.

Those are some of the factors that underlie and become the root of the birth of the khidmah tradition in pesantren. There may be other factors that have not been mentioned, which can be explored and added, according to the unique profile of each kyai, as well as the diversity of characteristics of Islamic boarding schools, at different times and places.

\section{Motivation to be Khidmah}

As for motivation, in general, three motivations encourage students to do khidmah such as firstly, to get the pleasure or willingness of the teacher. As a logical consequence of the belief in the greatness of the position of the kyai, namely as a pious and pious person, the santri hope to get the love and pleasure of the kyai. Ridha a kyai is believed to have a big role and influence that will lead to success in learning. Not only in terms of understanding and mastering science but what is more important is in obtaining the blessings of knowledge, even related to the success of his life in the future.

So, the blessing of the kyai is an invaluable provision that is always awaited to achieve success, both when studying at the cottage, and even more so when entering the community. If the

kyai is satisfied and has blessed a student, it is hoped that he will continue to pray for the good of the student who, God willing, will be approved by Allah Ta'aala. Therefore, students who understand this problem will try to do whatever will make 
the teacher happy and pleased with him. One of the popular utterances spoken to the students, among others, in the words of Abuya Sayyid Muhammad bin Alawi al-Maliki:

$$
\text { ثبات العلم بالمذاكرة، وبركته بالخندمة، ونفعه برضا الشيخ }
$$

"The attachment of knowledge is obtained through mudzakarah, its blessings are with khidmah, and its benefits are obtained by the pleasure of the teacher." Or in another popular expression: "Knowledge is achieved by learning, blessings are obtained by virtue, and the benefits of knowledge are obtained by obeying the teacher." This word of wisdom is attributed to as-Shaykh Muhammad bin Ismail Zain al-Yamani.

Parallel to this, the students were also very careful not to do anything that would hurt the kyai's heart and make him angry. Because if the kyai feels hurt and angry by something a student has done, it may be the cause of the obstruction of success and the loss of the blessings of knowledge. A condition that is certainly very feared and avoided by every student. In the book Ta'limul Muta'allim mentioned warnings not to hurt the teacher, namely;

$$
\text { فمن تأذى منه أستاذه يحرم بركة العلم ولا يتنفع بالعلم إلا قليلا }
$$

"Whoever offends his teacher, will be deprived of the blessing of knowledge, and his knowledge will not benefit except a little." (az-Zarnuji, 2013).

Second, as an expression of acknowledgement of goodness (al'i-tiraf bil jamil) to the kyai, and a form of gratitude for all the things that the kyai has given to the students. Every santri certainly feels how great and invaluable the services of his kyai, who selflessly and tirelessly, have educated him with religious sciences, morals, and various other sciences for a long time. His kyai patiently and painstakingly, with his various difficulties and problems, has guided him from before as a child who did not know anything and was nothing, to become a man of character, knowledge, and maturity. It is no exaggeration to say that all of these are forms of great struggle and sacrifice, which will never be repaid or replaced forever. And indeed, for all that he has done for the students, the kyai does not expect anything except the pleasure of Allah, and the aspiration that his students will become pious people and their knowledge will be useful.

Now, living up to all the goodness and sacrifices of the kyai (al-i'tiraf biljamil), then the students feel indebted and want to repay the kindness of their kyai as best they can, namely with khidmah. With his pure self-awareness and the promptings of an honest conscience, he will surely lead a santri to do whatever he can, whether requested or not, whether he was a student or graduated, to serve, serve, and help the kyai. in various ways, so that it will make him happy and spacious.

Third, want to get the virtues and benefits of such great wisdom, especially the blessings and benefits of knowledge. This, more or less, has become an understanding and belief that is imprinted in the souls of the santri obtained through the kyai's advice, ustadz's advice, recitation materials, or from stories they hear or read from various sources. Quoting the explanation given by Buya Yahya in one of his tausiyah, that the santri should be happy to be khidmah, because of its great virtue in bringing the wealth of knowledge. So it is the santri who need guidance, not the kyai or the islamic boarding school who need guidance. 


\section{The Theological of Khidmah}

What is meant by theological foundations here are the basics that can be used as a basis for the validity of the khidmah tradition, both those originating from the Qur'an, hadith, atsar, or the words of the scholars and rational arguments ('aqli) as reinforcement from our observations, here are some evidence that can be used as a reference for the truth of the khidmah tradition, namely:

First, there are many religious texts - both from the Qur'an, hadith and atsars, which explain the virtue of knowledge, praise for the claimant of knowledge, and the glorification of scholars not in the right place to mention or explain this. in detail here. This issue is very clear, widely known and agreed upon by Muslims. So it is said that Islam is a religion of knowledge, built on knowledge, obliges to study, glorifies the claimant of knowledge and the scholars. Among the texts that are very important, popular, and explicit in this matter-to mention one only-is the word of Allah Ta'alaa in the Qur'an Surah al-Mujdalam verse 11, namely:

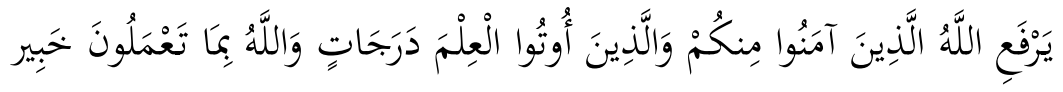

"Allah will exalt those who believe among you and those who were given knowledge by several degrees. And Allah is Knowing of what you do."

Imam Syaukani in his commentary, Fathul Qadir, explained that the glory that Allah promised to the scholars was a noble position in this world and the hereafter. So, with the fact that many texts explain the noble position of the scholars, logically, the logical conclusion that can be drawn is that as a consequence we must respect the scholars and fulfil their rights. As one scholar said, if Allah only elevates the position of the scholars and praises them, the servants who have experienced the benefits and virtues of the scholars should be able to honour them more.

As for the hadith, we mention one narration from the Prophet which contains a warning as well as an order that we pay attention to and fulfil the rights of the scholars, as a condition for obtaining recognition as the people of the Prophet, namely:

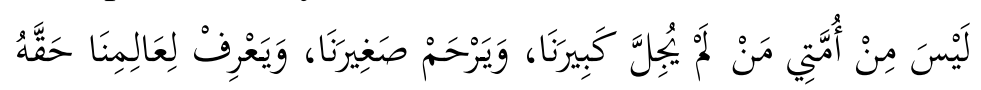

"It is not among my ummah who does not respect the elders, does not love the younger ones and does not understand the rights of a scholar." (H.R Ahmad).

Departing from the explanation above, then teachers, ustadz, kyai, sheikh - and anyone who is a science expert, must always be honoured and given their rights to the fullest. One form of respect and fulfilment of the rights of the ulama, in a long-standing good tradition among the Muslim community, is to pay attention to teachers. In short, serving and serving the teacher is one of the manifestations of the Shaykh's ta'dhimus which is not only allowed or reasonable but also must be done by students to their teachers because it is a religious order.

In line with this, if you think about it more deeply, there is a hadith of the Prophet which explains that the angels spread their wings for the students of knowledge, and the inhabitants of the sky, as well as the fish in the sea begging for forgiveness from the scholars (Narrated by Abu Daud and Tirmizi). is a form of respect as well as their khidmah to the experts of science. The content of this hadith provides lessons and cues, so that we imitate it, to serve the experts of knowledge. 
Second, there are religious teachings that command us to be grateful (syukr) and repay kindness (i'tiraf biljamil) to those who have done well to us. We mention here two important hadiths regarding this matter:

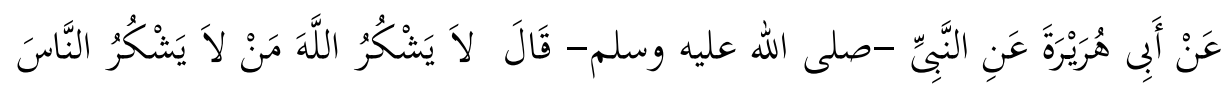

Meaning: "Abu Hurairah radhiyallahu 'anhu said that the Prophet Muhammad sallallaahu 'alaihi wasallam said: "No one is grateful to Allah who is not grateful to humans." (Narrated by Abu Dawud). Then the following hadith:

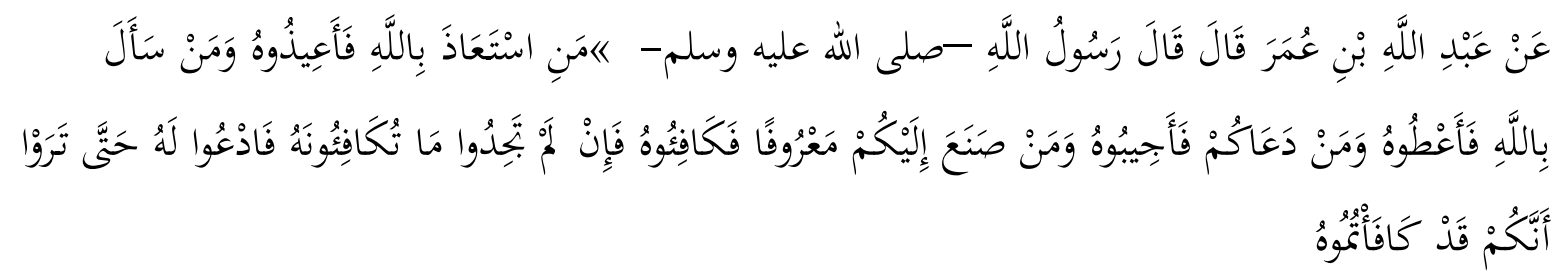

"Abdullah bin Umar radhiyallahu 'anhuma said: "The Messenger of Allah sallallaahu 'alaihi wasallam said: "Whoever asks for protection in the name of Allah then protect him, whoever asks in the name of Allah then give him, whoever invites you then attend (his invitation), and whoever does good to you, then repay him, if he does not find something to repay him, then pray for him, until you see that you have paid him back."(Narrated by Abu Dawud).

The first hadith contains a lesson that the right way to be grateful for favours is not only vertical to Allah alone. But the perfection of gratitude to God can be achieved if someone is willing to thank (in a broad sense) fellow human beings as the party who is the wasilah for the coming of favours.

While in the second hadith, religion explicitly commands us to appreciate a good by doing a favour or service. And it is implied that the form of reciprocation that must be given to those who have done good to us, is not merely verbal, formality, or perfunctory, but in the form of a recompense that is minimally commensurate, and will be much more perfect and commendable if replying with something better.

That's the $a d a b$ that religion guides us in terms of muamalah treating those who have done ihsan to us. At this point, we can reflect, think about and assess the goodness that has been given by a teacher to his students, or by a kyai to his students. The virtues in the form of scientific and moral guidance are invaluable in terms of form, and innumerable in terms of numbers. The virtues that lead us to the path of knowing God, understanding the Shari'a, understanding the sunnah of the Prophet, having good morals, to achieve safety and happiness in the hereafter. For those who have given us it all, and for those who are the heirs and caliphs of the Prophets, of course offering the best guidance for them, is a necessity.

Third, follow the sunnah (examples) of the companions of the Prophet in khidmah to the Prophet as their Supreme Master. History records that some of the Companions have undergone the kidmah to the Prophet such as Anas bin Malik and Abdullah bin Mas'ud. These two companions were known as khadimr Rasul (servants) because they were so intense in serving the Prophet, they became so close that they were often considered part of the Prophet's family. And 
history also records that these two friends received great blessings where Sababat Anas was ordained as the third person who narrated the most hadiths while Abdullah bin Mas'ud became a pious friend in the field of the Qur'an and fiqh.

The sunnah of friends in khidmah and glorifying the experts of knowledge is not only addressed to the Messenger of Allah, but to fellow friends who are more pious among them. In the book Adab al-Talib Ma'a Syaikhihi, there is a subtitle at-talib yakhdumu syaikhahu (ar-Rabi'i, 2015) it is stated that the friend of Ibn Abbas, a pious friend and an expert in the interpretation of the Qur'an and a from the Experts of the Prophet's Temple once guided the ropes of Zaid bin Thabit al-Ansari's vehicle, simply because he glorified the knowledge of Zaid's companions, saying, هذا, This is how we were ordered to treat our scholars." Until Umar's friend once said: تواضعوا لمن تعلمون منه "Please be tawadhu' yourself to the person who taught you".

\section{E. The Virtues and Benefits Khidmah}

Kindness to the teacher, no doubt has several virtues and benefits. Some of them that can be mentioned here for the first, to gain the pleasure of Allah and His reward. As described in the previous sections, khidmah is a form of obedience to Allah, who has ordered us to respect the scholars and fulfil their rights. Likewise, khidmah is a form of gratitude and reciprocation to the teacher for all his sacrifices and guidance, both of which are also part of religious orders. With sincere and earnest khidmah, it is hoped that Allah will be pleased with a student, to provide convenience in learning, as well as useful and blessed knowledge.

In the book Adabul Alim wal Muta'allim, Hadratus Shaykh Muhammad Hasyim Asy'ari clearly emphasizes this issue, "a student should submit to the teacher in all his affairs, follow all guidance, expect the pleasure of the teacher from what he does, and try to give respect maximum. So he does taqarrub to Allah by serving his teacher (wayataqarrabu ilallah Ta'aalaa bikhidmatihi).

Likewise in the book Ta'limul Muta'allim, it is stated that al-Qadhi Imam Fakhruddin alArsbandi is the head of the Imams in the Marwa area, who is highly respected by the Sultan. He stated that the noble position he obtained was due to his khidmah (serving) to his teacher, namely Abu Yazid ad-Dabusi, including in kitchen matters such as cooking food for the teacher.

Second, get the willingness and love of the teacher. The willingness and love of a teacher is something important because it will be wasilah and sabab, for learning success, blessings and benefits of knowledge, even happiness in life. In a simple understanding of the context of horizontal relationships, when a teacher is willing and in love, he will pray a lot for the student, and be happy to impart his knowledge to him. Regarding this Sayyid Muhammad bin Alawi alMaliki said:

$$
\text { الطالب عندي من يتعلم ويخدم، ومن يخلص في خدمته يفتح الله عليه }
$$

"A true disciple for me learns as well as khidmah. And whoever does khidmah sincerely, Allah will give faith to him." 
Third, khidmah can be a means of tarbiyah for a student to learn tawadhu ', respect and obey the teacher. With khidmah, this attitude of tawadhu is expected to become a deeply embedded trait, or character that is imprinted in a student. The nature of tawadhu is owned by a santri, because in addition to making it easier for him to gain knowledge, it will also keep him from being arrogant when he becomes a pious person or character, thus saving him from destruction.

Fourth, khidmah will provide a wider opportunity for someone to interact and get to know the teacher. And this means that it will provide opportunities to learn more from the teacher with direct experience, not only related to scientific issues but about many things such as morals, leadership, role models in the family, society and so on. Not only that, the close and intense interaction will make the example and the wisdom gained remain firmly engraved in his heart. Just like the saying of wisdom, ليس المعاينة كالمخابرة It is not the same between seeing directly and just hearing." Imam as-Samani said. "There were five thousand people who attended Imam Ahmad's assembly. Five hundred of them wrote, and the rest aimed to take an example from Imam Ahmad's morals and etiquette."

Fifth, khidmah can be a reason to get guidance from other people at a later time or later in the future. Because Allah has promised and determined that it is not a good thing except that it will be rewarded with goodness too (Surah Ar-Rahman: 60). So among the words of scholars that are often conveyed are من خدم خدم meaning,"whoever does khidmah, then he will get khidmah," as an encouragement to khidmah. It is not only getting a similar khidmah in the future, but can get glory. As said; وكم خدم الطلاب النبلاء مشايخهم النبلاء وتشرقوا بدلك" How many civilized santri, do khidmah to the noble masyayikh, then in the future they are given honor because of that khidmah." (arRabi'i, 2015).

Sixth, khidmah is a vehicle that will maintain the relationship between students and teachers, especially the khidmah that alumni do after graduation by continuing to maintain friendship and communication with post-study teachers, a student still has the opportunity to obtain guidance and advice from his teacher on various issues, including a reprimand if he makes a mistake, always together and live with the scholars, especially with the teachers themselves who are pious and pious, it is hoped that it will bring benefits and blessings. As the Prophet said in his saying: الَْرَكةُة "Blessings are with your parents (ulama)." (Narrated by Ibn Hibban and Hakim).

Related to this, Hadratus Shaykh Muhammad Hasyim Asy'ari mentions in more detail that a student must protect the rights of his teacher; pray while still alive and after death. Pay attention to descendants, relatives, and loved ones. If he dies, he should visit the grave of his teacher, make istighfar for him, and give charity for him."

Furthermore, in modern times, of course, this khidmah tradition is very relevant to be applied and preserved. This is because today's education is becoming more and more pragmatic and transactional. The relationship between students and teachers is dry, and it is only a formality in the classroom. Likewise, morals towards teachers began to erode in very poor conditions. On 
the other hand, some people only see learning success from academic and cognitive aspects. Taking into account this reality, it is understandable, the need for mutual understanding and cooperation is great to cultivate and preserve khidmah.

\section{CONCLUSION}

After conducting the presentation and discussion on the previous pages, the author can draw several conclusions, khidmah is a form of devotion and service performed by a student (santri) to his teacher (kyai), as a form of respect and obedience to the teacher. This devotion can be in the form of devotion that has physical nuances, thoughts, possessions, or in the form of prayer. The emergence of a khidmah tradition in Islamic boarding schools and other Islamic educational institutions is motivated by several factors such as strong moral education, especially morals for teachers (kyai), kyai who is believed to be pious, pious and holy people, and the dormitory life system in the community, a long period which builds an inner closeness between teacher and student. Some of the motivations that encourage students to be khidmah are: to get the kyai's willingness (ridha) as well as an expression of gratitude and want to repay the kyai's services. The theological foundation of the khidmah tradition is very strong, because it is based on several arguments such as the many verses of the Qur'an and the hadiths of the Prophet that commanded to glorify the ulama and fulfil their rights, as well as the living example of the companions of the Prophet who had given solemn example.

Among the virtues and benefits of khidmah such as obtaining the pleasure of Allah and the

teacher who will bring blessings and benefits of knowledge, instilling an attitude of tawadhu', extensive direct opportunities to study teacher morals, getting the same khidmah in the future from others, and being able to continue to maintain communication with teachers. In modern times and the future, khidmah and its values remain relevant to be cultivated and preserved, to maintain the quality of education that has character and is based on spiritual values, so that it can produce useful and blessed knowledge.

\section{REFERENCES}

An'im, Abu. (2012). The Secret of Imam Shafi'i Success. Tt.: Mu'jizat Group, 74.

An'im, Abu. (2015). Tips for Success of Salaf Scholars in Seeking Knowledge. Ttt: Miracle Group. 131132.

Al-Ajurri, Abu Bakr Muhammad bin al-Husayn bin Abdillah. 2013. Akhlaq al-'Ulama'. Riyadh: Dar alQabas.

Al-Masudi, Hafidz Hasan. Ttt. Taisirul Khallaq Fi Ilm al-Akhlaq. Ttt: al-Haramain. 7.

Arfa, Faisal Ananda and Watni Parpaung. (2018). Islamic Law Research Methods. Jakarta: Prenadamedia Group. 16 and 112.

Asy'ari. KH. Muhammad Hashim. Adabul 'Alim wal Muta'allim. Jombang: Maktabah Turots al-Islami.

Ba'athiyah, Muhammad Ali. (2018). Mysticism; Guidelines for Obtaining Happiness in the Hereafter. Bantul: Layar. 
Barjas, Abdussalam. (2010). 'Awaa'iq al-Talab. Egypt: Daar al-Furqan. 84-86.

Djauhari, KH. Mohammad Tidjani. (2008). For my students; Message and Hope. Jakarta: TAJ Publishing Faqih, KH. Abdullah. Pearl Advice KH. Abdullah Faqih. Tuban: LTN Langitan. 77-78.

Al-Ghazali, Abu Hamid. (2014). Ayuhal Walad; Advice of al-Imam al-Ghazali to his students. Surabaya: Pearl of Science.

Al-Ghazali, Abu Hamid. (1995). Summary of Ihya 'Ulumiddin. Jakarta: Amani Library.

Hajar M. (2017). Approach Models in Legal and Fiqh Research. Yogyakarta: Kalimedia. 90.

Imam, Sayyid. (2014). Mandatory Knowledge of Every Muslim. Translation of Aqsam al-'Ilm al-ladzi Huwa Fardh 'Ain. Klaten: Inas Media.

Al-Qasim. Abdul Malik bin Muhammad. (2005). Prophet's heir; Collection of History of Previous Scholars in Studying Knowledge. Jakarta: Darul Haq.

Ar-Rabi'i, Aid bin Muqbil. (2015). Adab at-Talib Ma'a Shaykhhi. Cairo: Dar Umar bin Khattab. 53.

Ar-Raudhah. Book Study Group. (2017). Methods of Demanding Knowledge Ala Salaf. Solo: Arofah Library, 74.

As-Sadhan. Abdul Aziz bin Muhammad. (2006). Guidance for Studying Science. Jakarta: Pustaka a-Tazkia.

Sa'id, M. Ridwan Qayyum. (2006). Fuqaha's Secret of Success. Lirboyo: Gayatri's partner.

Shakir. Muhammad. Ttt. Wasaya al-Abaa' li al-Abna. Ttt: al-Hidayah.

As-Syinqithy, Ibrahim bin Ubbu al-Hasany. (2017). Rihlah Tahfidz; Methods of Education and Memorization of the Qur'an Ala Ulama Syinqith. Lirboyo: Lirboyo Press. 85-86.

Tanzeh. Ahmad. (2011). Practical Research Methodology. Tulungagung: Terrace. 48, 49, 50 64, 71, and 97.

Al-'Utaibi, Osama bin 'Athaya. (2012). Mu'awqaatun Fi Tariq Thalab al-'Ilm. 'Ain Shams: Daar Sabiil alRashaad.

Al-'Utsaimin, Muhammad bin Salih. (2016). Complete Guide to Studying Knowledge. Jakarta: Library of Ibn Kathir. 11, 20 and 46.

Al-Zarnuji, Burhanuddin. (2013). Ta'lim al-Muta'allim; Tariq al-Ta'lim. Jakarta: Daar al-Kutub alIslamiyah.

Zayd, Bakr bin Abdullah Abu. (1415 H). Hilyah Talib al-'Ilm. Riyadh: Daar al-'Aashimah. 